2. Mishlanova, S.L., Utkina, T.I. (2008). Metafora v nauchnopopulyarnom meditsinskom diskurse: semioticheskiy, kognitivno-kommunikativnyy, pragmaticheskiy aspekty [Metaphor in the scientific-popular medical discourse: semiotic, cognitive-communicative, pragmatic aspects]. Perm: Perm state university [in Russian].

3. Tarasova, N.P. (2013). Metaforicheskoye modelirovaniye epidemii $v$ mediynom diskurse: na materiale russkikh i nemetskikh tekstov [Metaphoric modeling of epidemic in media discourse: based on Russian and German texts] (Doctoral dissertation). Perm: Perm state national research university [in Russian].

4. Covello, V.T., Peters, R., Wojtecki, J., Hyde, R. (2001) Risk communication, the West Nile virus epidemic, and bioterrorism: responding to the communication challenges posed by the intentional or unintentional release of a pathogen in an urban setting. Journal of Urban Health, no. 78(2), pp. 382-391. DOI: 10.1093/jurban/78.2.382 [in English].
5. Hinnant, A., Len-Ríos, M.E. (2009). Tacit Understandings of Health Literacy Interview and Survey Research with Health Journalists. Science Communication, no. 31(1), pp. 84-115. DOI: 10.1177/1075547009335345 [in English].

6. Infanti, J., Sixsmith, J., Barry, M., Núñez-Córdoba, J., Oroviogoicoechea-Ortega, C., Guillén Grima, F. (2013). A literature review on effective risk communication for the prevention and control of communicable diseases in Europe. Stockholm: ECDC. DOI: 10.2900/64747 [in English].

7. Martin, P., Martin-Granel, E. (2006). 2,500-year Evolution of the Term "Epidemic". Emerging Infectious Diseases, no. 12(6), pp. 976. DOI: 10.3201/eid1206.051263 [in English].

8. Wright, M. (2009). A Sick Game to Play. Games Based on Swine Flu have Spread Rapidly Online. Are they in Bad Taste, or do they Fulfil a Cathartic Role? Retrieved from: http://www. theguardian.com/technology/2009/may/14/ games-swine-flu/ (last accessed: 10.02.2019) [in English].

UDC 81'253:82-193.1:791

DOI 10.32999/ksu2663-3426/2019-1-34

\title{
TRANSLATION OF RIDDLES IN FILMS: COMMUNICATIVE AND COGNITIVE ASPECT
}

\author{
Tashchenko Ganna Volodymyrivna, \\ $\mathrm{PhD}$ in Philology, \\ Associate Professor of the Mykola Lukash Translation Studies Department \\ V. N. Karazin Kharkiv National University \\ annatashchenko91@gmail.com \\ orcid.org/ 0000-0002-9008-4935
}

\begin{abstract}
The article considers structural and cognitive characteristics of riddles in film translation. Artistic riddles do not follow any specific patterns from the standpoint of the methods used for encoding the answer to be guessed. Consequently, they pose a variety of challenges for the translator. The clues the riddler gives can be embodied in a rhyme, an anagram, they can be based on the play of words or resemble folk riddles with their inherent abstract imagery. However, every riddle proceeds from a certain communicative strategy. Seemingly designed to prevent the guesser from obtaining what they wish, riddles are meant to check if the seeker is worth the "prize". The guesser potentially possesses the knowledge and skills required to find the answer, though it may take considerable effort. The sufficiency of clues necessary to reach the solution corresponding to the original constitutes a major factor of the riddle translation. Nevertheless, the structural component plays an equally important part in terms of preserving the aesthetic influence of the riddle. Sometimes, it is even crucial to ensure the appropriate visualization on the screen or to provide for the consistency of the plot. Anagrams can be rendered on the basis of rearrangement of letters in the target language. The successful reproduction of rhythm and rhyme heavily depends on the nature of the images underlying the riddle, how abstract or concrete they are, whether they allow for a certain degree of modification without disturbing the connection of the riddle and the answer. The foreign-language component shall be naturally entwined in the translation, preferably retaining its "otherness". The play of words is a complex problem in itself. In riddles it is even more relevant to recreate the play, since its omission may not only affect the overall aesthetic function of the original but also blur the images vital for finding the correct answer. In films the issue of riddles translation becomes more multifacet as their rendering requires taking into account the correlation between the textual aspect of the riddle and the events unfolding on the screen.

Key words: anagram, communicative strategy, riddle translation, rhyme, word play.
\end{abstract}

\section{ПЕРЕКЛАД ЗАГАДОК У ФІЛЬМАХ: КОМУНІКАТИВНИЙ ТА КОГНІТИВНИЙ АСПЕКТ}

Тащенко Ганна Володимирівна, кандидат фрілологічних наук, доцент кафедри перекладознавства імені Миколи Лукаша Харківський національний університет імені В. Н. Каразіна annatashchenko91@gmail.com orcid.org/ 0000-0002-9008-4935 
У статті розглянуто структурні та когнітивні особливості перекладу загадок у фрільмах. Оригінальним загадкам не притаманні жодні моделі побудови з огляду на засоби кодування розгадки. Як наслідок викликають різноманітні труднощі під час перекладу. Підказки, які дає той, хто загадує загадку, можуть втілюватися у вірші, складати анаграму, можуть грунтуватися на грі слів або нагадувати народну загадку з притаманними їй абстрактними образами. Проте кожна загадка базується на певній комунікативній стратегії. Незважаючи на те, що загадка, здається, призначена, щоб не дати тому, хто їі розгадує, отримати те, чого він бажає, вони мають на меті перевірити, чи вартий він нагороди. Той, хто шукає розгадку, потенційно володіє знаннями та навичками, необхідними для відповіді, хоча її вирішення може вимагати значних зусиль. Достатність підказок, що необхідні для вірної розгадки, яка відповідала б оригіналу, є важливим фрактором перекладу. Однак формальний компонент відіграє не менш важливу роль у збереженні естетичного впливу загадки. Іноді він має вирішальне значення для забезпечення належної візуалізації на екрані або цілісності сюжету. Анаграми можуть відтворюватися на основі перестановки літер у цільовій мові. Успішне збереження ритму та рими значною мірою залежить від специфріки образів в основі загадки, наскільки абстрактними або конкретними вони є, чи підлягають вони певним модифікаціям без порушення зв'язку між загадкою та розгадкою. Іншомовний компонент має природним чином вплітатися у переклад, при цьому бажано, щоб він не втратив своєї «іншості». Гра слів є складною перекладацькою проблемою. У перекладі загадок навіть більш релевантним є відтворення гри слів, оскільки їі нівелювання може вплинути не тільки на загальну естетичну функцію оригіналу, але й розмити підказки, що є надважливим для правильної відповіді. У фільмах проблема перекладу загадок є більш багатоаспектною, оскільки під час їх передачі необхідно враховувати співвідношення між текстовим аспектом загадки та подіями, що розгортаються на екрані.

Ключові слова: анаграма, гра слів, комунікативна стратегія, переклад загадок, рима.

\section{Introduction}

Riddles have been widely discussed in numerous studies, which, however, were mostly concerned with folklore riddles as a manifestation of national identity or culture-specific cognitive mechanisms of knowledge representation. The linguistic aspect of riddles is well-established unlike the specifics of their translation including the reasons for the difficulties the translator may encounter. Unlike folk riddles, artistic ones are produced by the imagination of the screen writer, consequently, they vary greatly from the point of view of their form, images underlying the code for a specific answer, correlation between the text and its visualization on the screen.

The object of the research is the riddle as a textual unit, "a product of cognitive and communicative creativity which expresses the subject, logical, aesthetic, figural, emotional and evaluative information about the reality" (Захарова, 2009: 6). The subject of the study is constituted by the structural, formal and cognitive specifics of the riddles and their influence on the selection of translational methods. The research is aimed at determining the correlation between the formal representation, cognitive and communicative value of the riddle and the method of translation to be chosen.

\section{Overview}

O. O. Selivanova defines riddle as "a discourse which represents a dialogical unity of the riddle and the answer embedded in the interactive space of the communicative situation whose semiotic mediator is a text describing, in a transformed or an incomplete form, the denotation as governed by the communicative strategies of prompting and ciphering" (Селиванова, 2014).
The significance of the riddle being qualified as a discourse lies in the fact that it reveals its communicative and situational nature. The riddling process, by definition, is based on a dialogue, interaction of communicants pursuing their own objectives. However, if folk riddles mostly function as a source of national wisdom having a fixed structure and mostly decipherable regardless of the context, artistic riddles found in literature or cinema challenge the general idea of a "question-answer" combination, they "vividly manifest the arbitrary will of the human mind, in particular linguistic consciousness, and its reluctance to fit into any limits or categories (Левин, 1978: 284). Artistic riddles follow no specific algorithms either from the point of view of their structure or solution. They may vary from joking questions where entertainment is the principal goal of riddling to wisdom questions where there is no single answer but the answer must be smart and true. However, riddling always pursues a certain aim as the answer allows the guesser to obtain what he seeks, to find his path or even to remain alive.

Thus, riddling represents a specific linguistic behaviour with an underlying communicative strategy as "a set of speech actions aimed at achieving the communicative goals" which "includes the planning of speech activity depending on the communication conditions and the identity of communicants as well as its implementing" (Иccepc, 2008: 125).

The strategy, riddling is based on, combines both pragmatic and cognitive components, as the process presupposes certain actions both on behalf of the riddler and the guesser, at the same time the riddler presumes that his "opponent" 
possesses knowledge sufficient to find the answer. "Taken as a whole $<\ldots>$ from the riddler's point of view the riddle is both a test of the guesser's equality and a matter of forcing the guesser to demonstrate his equality" (Jolles, 2017: 105). Riddle orientation at a specific addressee determines its reception and further search for the solution proceeding from the clue given. Sometimes the answer comes when the guesser simply gives it a thought and sometimes he/she must go through several stages or even several riddles in order to reach the desired key. However, though the riddle by definition provides for multiple answers and poses difficulties for the guesser, it is mostly constructed in a manner which allows the intended person to find the solution with some effort.

M. Foucault once said "not everything can be said, not everything can be talked about, not everyone can be spoken to and not under all the circumstances" (Фуко, 1996: 51). Artistic riddles are designated for those who are knowledgeable or intelligent enough. They trigger mental operations which permit to actualize the fragment of knowledge against the background of which the answer can be found. The riddler may intend to prevent the guesser from obtaining what he wishes, nevertheless, the riddle provides enough information for the guesser to decipher the code. Inventing his riddles, the author/screen writer unfolds a communicative space between the riddler and the guesser.

\section{Results and discussion}

From the point of view of their translation, the riddles pose difficulties both in terms of their form and communicative orientedness. The former allows the riddle to play an important aesthetic, emotional and entertaining function within a film. The latter provides for consistency of the riddle itself and the expected answer. Preservation of the communicative function prevails. However, the structural and formal aspect of the riddle does not lose its relevance not only from the perspective of emotional impact but also from the standpoint of consistency of the story. If a riddle is written in verse and is positioned as such in the film, the viewer may be confused by a translation lacking both rhythm and rhyme.

A specific type of riddles is constituted by anagrams created through rearrangement of letters to obtain a word or phrase. However, the letters and the words they form in the original cannot possibly correspond to a meaningful combination in translation. The most natural method of rendering an anagram is to create one which would produce the same key in the target language.
When the librarian and his guardian find an anagram on the place where Prospero's staff is supposed to be hidden, they read the following: "The Guns Bind Gab". The coded phrase in full says "Things bad begun make strong themselves with ill" which is a quote from "Macbeth", a literary work whose plot is intertwined with the entire logic of the hiding-place. While trying to decipher the anagram, Eve, the guardian, recollects a quote from Macbeth matching the code.

The translator opts for a variant which allows for arranging the letters in the manner to obtain the same quote in the target language, thus changing the original. Consequently, "The Guns Bind Gab" is transformed into «Лоза в очах помітна», while Shakespearean words turn into their Ukrainian equivalent «Хто злом почав, той кличе й далі лихо». The librarian's attempts to guess the answer are also reproduced in a completely different manner which corresponds to the Ukrainian-language anagram.
"The Guns Bind Gab.
Лоза в очах помітна.
Bind gab.
Words we don't say.
Лоза в очах... Нi, якась
No, "Macbeth" again? No,
there's no quotes about guns in "Macbeth.
"If it's a code, we need some sort of cypher to solve it.
Unless it's a self-contained anagram.
Ooh! I like anagrams.
Guns bind gab.
Guns bind gab.
No, uh Bathings bunged.
- Now that better not be it.
- No.
Bad begins - Ah! - Hmm?
"Things bad begun make
strong themselves with ill.
"Macbeth, "Act III, Scene II.
нісенітниця. Це що, теж з Макбета? Нi, там
немає таких слів.
Якщо це код, то
потрібен шифр, хіба що це - часткова анаграма.
Обожнюю анаграми.
Лоза в очах, лоза в
очах помітна... Заочна помста, ні, зло в очах?
Так, це більше схоже.
Hi. Зло почав.
А! Хто злом почав, той кличе й далі лихо.
Макбет, акт третій,
сцена друга (Бібліоте- карі).

(The Librarians)

Another translational problem is represented by the riddles characterized by rhyme or rhythm. They require not only preserving the meaning which would allow the guesser to solve the problem but also reproducing the form to exert the same aesthetic influence.

Sometimes, riddles in cinema use generalized images, proving close to folk riddles which code natural phenomena, human qualities, everyday items, etc. Therefore, translators have more tools necessary to preserve their form. Looking for the appropriate rhymes, they are freer in the choice of lexical means, as their only goal is to provide the guesser and, correspondingly, the reader with a riddle which would lead to the same answer.

In the following example, rendering Gollum's riddle about the wind, the translator uses the poetic form characteristic of the source. 
Voiceless, it cries, Wingless, it flutters,

Голос-смерч

Крила-хмари

Toothless bites,

Mouthless mutters. (The

Hobbit: An Unexpected

Journey)

Вічний утікач,

Вічно у мандрах.

Вітер. (Гобіт. Неочікувана подорож)

Though the rhyme is lost, the rhythm and short, concise lines follow the original riddle which gives the translator an opportunity to reconstruct the impact of the source from the formal point of view. Still, another aspect of the riddle presentation is omitted. Parallel constructions used in the English-language riddle allow for creating a paradox where such actions as crying, fluttering, biting and muttering are performed by something or someone inherently unable to do so. Thus, the imagery of the original is partially disrupted, as the translator does not reproduce the grammatical parallelism from the target riddle as well as changes some of the components the source metaphorical representation of wind proceeds from. In this manner, toothless biting and mouthless muttering are removed while the idea of continuous traveling emerges. All the changes, made by the translator, nevertheless, do not produce a negative influence on the general communicative strategy implementation. The images offered by the translator are powerful enough to guide the guesser to the correct answer.

However, some riddles in verse pose increased requirements to the translator, as, in addition to preserving the formal presentation of the riddle, they presuppose much more precision in terms of the content and the core images. In "Harry Potter and the Goblet of Fire", the protagonist is supposed to find out what the following task in the tournament is going to be by solving the riddle shown in the example.

Come seek us where our voices sound.

We cannot sing above the ground.

An hour long you'll have to look

To recover what we took. (Harry Potter and the Goblet of Fire)
Шукай нас там, де нашу пісню чути, На суші ми німі $\mathrm{i}$ вельми скуті.

I повернути скарб і віднайти,

На все годину часу

маєш ти. (Гаррі Поттер і келих вогню)
The riddle is hidden in a golden egg which unveils its secret when opened under water, otherwise it only gives a sharp cry, which is tightly connected with the answer - mermaids. For this reason, the reference to their voices being muted on land is the key one for understanding which creatures are described. The second part of the riddle is rather explicit. It says that the contestants will have no more than an hour to bring back whatever the mermaids have taken away. The translation quite closely follows the original

both in terms of the form and meaning, while the second part of the riddle becomes more specific as the translator uses the word «скарб» ("treasure") to show that the mermaids will steal something important from the contestants. The remaining part of the riddle reveals its meaning during the competition when the participants learn that the persons they care about are captured at the bottom of the lake. Thus, the translation of the riddle can be considered successful as it provides the clues contained in the original and allows the further plot to add the rest.

The following example is even more challenging for the translator, because it represents a precise though metaphorical guidance which is supposed to show the way to Anne Boleyn's ring. The meaning of each line is relevant. The ring given to Anne Boleyn by her husband, King Henri VIII, was supposed to be passed to her daughter, Elisabeth. The riddle was intended for her, however, the queen did not manage to find her mother's jewel. Thus, the relic hunters are following the king's instructions a few hundred years after.

\section{As a}

jester toys with danger, Springing insults with a grin,

Vile falsehood

boxed inside Leeds

To god's mortal sin

And the sign of my love

that you wore with such

glee,

You must find by my

likeness

But first you must see

That the ring is the key

to the ring left to thee.

(Relic hunter)

The clues given by Henri VIII are rather specific. His favorite castle of Leeds holds an old piano. After playing one of the king's compositions, the historians find a secret room with a portrait of Henri at a young age, his "likeness". The painting shows him with a jack-in-the-box. The box is still exhibited in the museum. In this manner, the relic hunters find out that the ring has been in the box all the time.

The original riddle is characterized by a certain rhythm and rhyme, it includes old English forms, all of which are lost in translation, since the target riddle is not written in verse, while the archaic component is virtually inexpressible in Ukrainian. The translator, thus, preserves all the key elements of the riddle relevant for the plot and even provides a specified equivalent for "likeness" transforming it into «портрет» ("portrait"). Nevertheless, the viewer may be 
confused at hearing that the characters call the riddle a verse which helps them to remember it when the parchment where it was written is stolen.

In certain cases the linguistic aspect of the riddle is interrelated with its visualization on the screen. The lock, the librarian and his companion, vampire, encounter in the search for the Judas Chalice, shall be open by a combination of letters. The clue says: "The faith was breached. The mark was sealed". Considering the Christian background of the story, the characters reach the conclusion that the answer is "kiss", "baiser" in French.

As can be seen from the example, the translator partially changes the original which does not seem justified, since neither the structure nor the meaning of the riddle itself and the associations arising on its basis are unfamiliar for the Ukrainian audience. The story of Judas' betrayal is widely known in the Christian community which would allow the translator to preserve the images embedded in the original riddle. Nevertheless, the Ukrainian translation proves consistent providing the same solution and preserving the foreign-language component.

$\begin{array}{ll}\text { Combination lock. It will } & \text { Замок з шифром, його } \\ \text { be opened with the right } & \text { відімкне комбінація з } \\ \text { six letters. } & \text { шести літер. С навіть } \\ \text { The clue is in... } & \text { підказка. } \\ \text { French? } & \text { Знак... } \\ \text { The faith was breached. } & \text { Знак, яким було закарбо- } \\ \text { The mark was sealed. } & \text { вано долю } \\ \text { Violation, deception, } & \text { Знак долі, що це? Кар- } \\ \text { betrayal... } & \text { бувати крок? що це? } \\ \text { Betrayal. Sealed with a... } & \text { Слова? } \\ \text { With a kiss. You see, Judas } & \text { Поцілунок. Іуда визначив } \\ \text { signaled the Romans and } & \text { долю Христа, закарбу- } \\ \text { sealed Christ's fate with } & \text { вавши поцілунок на його } \\ \text { a kiss. And in French kiss } & \text { вустах. А французькою } \\ \text { is... } & \text { поцілунок... } \\ \text { Un baiser. (The Librarian: } & \text { Шп баікеr. (Бібліотекар: } \\ \text { Curse of the Judas Chalice) } & \text { прокляття Юдиного } \\ & \text { потиру) }\end{array}$

The following example does not pose any difficulties from the point of view of its form. However, it is based on a play of words which is not fully available to the viewer. Nostradamus whose prophecy is shown below refers to a person who is allegedly capable of saving "a man of greatness", the prince, calling this person the Fox. Conventionally applied to an animal, the lexical unit is used here as a proper name, the surname of a famous relic hunter, Sydney Fox. However, the translation does not reflect the play of words in any way as the transcoded surname of the character «Фокс» and the name of the animal do not correlate in the Ukrainian language and cannot possibly be expressed in a single linguistic unit. For this reason, the viewer may remain wondering how the prophecy mentioning an animal led the security agent of the royalty to the college professor and hunter for the treasures of the past, Sydney Fox.

The second thousand will Усе ще буде початок друstill be new,

When ruin will fall upon

a man of greatness.

The bird will deliver the

hunter.

The chase returns to the

place that it began,

And on the eve the Fox

will seek the 16 hundred гого тисячоліття,

Коли загибель випаде на долю шляхетного чоловіка Птах доставить мисливця. Погоня повертається туди, звідки й почалася.

Напередодні Лисиця шукатиме 16 сотень, And its light will save the (Мисливці за старовиною) Hound. (Relic hunter)

\section{Conclusions}

Therefore, artistic riddles require a variety of approaches in translation, as they differ both in their form and content. Film-makers often use anagrams to draw the viewer deeper in their story through close interconnection between what he hears and what he sees. In translation, however, the original anagrams cannot be considered appropriate by definition. Consequently, translators have to create their own anagrams which would compose the same answer. Anagrams generally make no specific sense, but they may be rooted in a certain culture, correlate with a historical period, mode of art, be written in a particular register etc, which shall be conveyed in translation.

Verse generally constitutes a complicated problem in translation, however, it is especially challenging in riddles, since translators are limited in changing the original images. Otherwise, the riddle will prove incongruent to the answer. Sometimes, the images encoded in the riddle as well the answer are of general nature referring to the objects or phenomena of everyday life, which provides the translator with a certain freedom in changing the verbal expression of the riddle in favor of its form, if necessary. Certain changes in the linguistic representation will not affect its communicative value, allowing the guesser to reach the same answer. Still, if the basic clues, the riddle contains, must be preserved to suggest the same solution, the translators' choices may vary. While some manage to produce riddles in verse on the basis of the images pertaining to the original, others sacrifice the formal aspect of the text in order not to lose any hints the guessers need. Word play presents a specific challenge for a translator due to asymmetry of the meanings linguistic units are able to convey in the interacting languages. 


\section{BIBLIOGRAPHY:}

1. Захарова Н.В. Лінгвокультурологічні особливості українських і німецьких народних загадок: структура, семантика, прагматика : авторефр. дис. на здобуття наук. ступеня канд. фрілол. наук : спец. 10.02.17 «Порівняльно-історичне і типологічне мовознавство». Київ, 2009. 20 с.

2. Иссерс О.С. Коммуникативные стратегии и тактики русской речи. Москва : URSS / УРCС; ЛКИ, 2008. 288 с.

3. Левин Ю.И. Семантическая структура загадки. Паремиологический сборник. Москва : Наука, 1978. С. 283-314.

4. Селиванова Е.А. Проблема дефиниции загадки. Науковий вісник Міжнародного гуманітарного університету. Серія «Філологія». 2014. Вип. 9. С. 150-154.

5. Фуко М. Воля к истине : по ту сторону знания, власти и сексуальности. Работы разных лет. Москва : Касталь, 1996. 448 с.

6. Jolles A. Simple Forms. London : Verso. 2017. 272 p.

\section{REFERENCES:}

1. Zakharova, N.V. (2009). Linhvokulturolohichni osoblyvosti ukrainskykh i nimetskykh narodnykh zahadok: struktura, semantyka, prahmatyka [Linguistic and cultural specifics of the Ukrainian and German Folk Riddles: structure, semantics, pragmatics]. Abstract of the thesis for PhD in Philology. Kyiv, $20 \mathrm{p}$.

2. Issers, O.S. (2008). Kommunikativnye strategii i taktiki russkoj rechi [Communicative strategies and tactics of the Russian language]. Moscow : URSS, $288 \mathrm{p}$.

3. Levin, Yu.I. (1978). Semanticheskaja struktura zagadki [Semantic structure of the riddle]. Paremiologicheskij sbornik - Paroemiological Collected Volume. Moscow : Nauka, P. 283-313.

4. Selivanova, Ye.A. (2014). Problema definicii zagadki [lssue of the definition of riddle]. Naukovij visnik Mizhnarodnogo gumanitarnogo universitetu - Scientific Bulletin of the International University of Humanities. Philology Series. Issue 9. P. 150-154.

5. Foucault, M. (1996). Volja k istine: po tu storonu znanija, vlasti i seksual'nosti. Raboty raznyh let. [Will for truth: beyond knowledge, power and sexuality. Works of different years]. Moscow: Kastal, 448 p.

6. Jolles, A. (2017). Simple Forms. London: Verso, 272 p.

\title{
АНТИЕТИКЕТНІ ФОРМИ СПІЛКУВАННЯ В АНГЛОМОВНІЙ КАРТИНІ СВІТУ (HA MATEPIAЛI POMAHY J.D. SALINGER “THE CATCHER IN THE RYE”)
}

\author{
Форманова Світлана Вікторівна, \\ доктор фрілологічних наук, доцент, профессор кафедри української мови \\ Одеський національний університет імені І.І. Мечникова \\ laly2009@ukr.net \\ orcid.org/0000-0001-9434-1903
}

\begin{abstract}
Метою статті є аналіз антиетикетних форм спілкування в романі Дж.Д. Селінджера «Ловець у житі», що передбачило розв'язання таких завдань: 1) з'ясувати основні підходи до визначення й уточнення поняття «антиетикетні форми спілкування»; 2) схарактеризувати фрорми антиетикетного спілкування; 2) класифрікувати їх за семантичною ознакою.

Методи дослідження - аналіз і синтез, індуктивний і дедуктивний методи - дали змогу теоретично осмислити сучасні дослідницькі підходи щодо формування антиетикетної мовленнєвої поведінки особистості; метод суцільної вибірки й контекстуально-інтерпретаційного аналізу було застосовано задля фрормування й обробки дослідницького корпусу фрактичного матеріалу.

Результати. Автором класиффіковано антиетикетні фформи спілкування на інвективу, сленг, слова-паразити, негативно-оцінну лексику, а також схарактеризовано тенденції формування мовлення персонажів, а саме Колхілда Холдена, в образі якого Дж.Д. Селінджер яскраво відобразив нонконформістські світовідчуття.

Поведінка Холдена - це виклик бездуховному існуванню суспільства й конформізму обивателя. Доведено, що естетичні погляди письменника проявляються в його фрілософрській свідомості через чуттєве пізнання світу, споглядальне й творче ставлення людини до дійсності, у суб'єктивному освоєнні довкілля через стан духовно-чуттєвої ейсрорії, піднесення, катарсису, духовної насолоди тощо. Своєрідність мовної картини світу Дж.Д. Селінджера полягає в новаторському підході до манери оповіді, зображенні персонажів, їхньої мови, способу зображення дійсності, ставлення головного героя до життя.

У результаті дослідження з'ясовано, що антиетикетні форми спілкування набувають об'ємного художньо-образного підтекстового значення, стають семантично багатомірними. Більшість із них, характеризуючись смисловою узуальністю, визначаються соціальною намагніченістю. Внутрішня індивідуально-авторська форма їх зумовлюється системно-образним ставленням Холдена до дійсності.

Висновки. Проаналізований матеріал дав змогу класифікувати антиетикетні фрорми спілкування за такими групами: 1. агресивні (спрямовані на людину, вживаються для нанесення образи); 2. експлетивні (лексичні одиниці, спрямовані на ситуацію, використовуються для вираження емоцій); 3. інвективи; 4. слене; 5. слова-паразити.

Таким чином, антиетикетне спілкування проявляється у стилістично зниженій лексищі, образі, негативних порівняннях тощо.

Ключові слова: антиетикет, антиетикетні форми спілкування, інвектива, сленг, слова-паразити, негативно-оцінна лексика, образа, мовна картина світу, англомовна картина світу.
\end{abstract}

